Simposium I Jaringan Perguruan Tinggi untuk Pembangunan Infrastruktur Indonesia, 2016

\title{
Penentuan Prioritas Penanganan Aksesibilitas Infrastruktur Kawasan Perbatasan di Desa Kumba Kecamatan Jagoi Babang Kabupaten Bengkayang
}

\author{
Ferry Juniardi, ST,MT ${ }^{1}$, Asep Supriadi ${ }^{2}$, Erwin Sutandar ${ }^{3}$, Heri Azwansyah, ST,MT ${ }^{4}$ \\ ${ }^{1}$ Universitas Tanjungpura, Pontianak, Indonesia \\ ${ }^{2,3,4}$ Universitas Tanjungpura, Pontianak, Indonesia
}

\begin{abstract}
Abstrak
Prioritas dalam penanganan infrastruktur dipilih sebagai upaya strategi terbatasnya dana yang ada. Studi ini bertujuan untuk menentukan skala prioritas penanganan aksesibilitas infrastruktur di Desa Kumba Kecamatan Jagoi Babang Kabupaten Bengkayang.

Studi ini membutuhkan data-data aksesibilitas dan kondisi infrastruktur dasar yang diperoleh dari instansi terkait, observasi lapangan dan interview. Studi ini menggunakan metode IRAP (Integrated Rural Accessibility Planning). Tingkat aksesibilitas menggunakan beberapa indikator aksesibilitas tiap infastruktur.

Hasil penelitian menghasilkan bahwa tingkat kesulitan aksesibilitas terbesar di Dusun Saparan dan Dusun Sindang Kasih adalah akses terhadap sektor pasar dengan nilai aksesibilitas masing-masing 15,422 dan 15,000. Intervensi utama yang dilakukan untuk perbaikan aksesibilitas terhadap sektor pasar adalah fasilitas dari sektor ini yaitu dengan membangun pasar atau tempat penampungan hasil di kedua dusun, dan intervensi kedua adalah penanganan prasarana transportasi berupa perbaikan jaringan jalan.
\end{abstract}

Kata kunci: infrastruktur, IRAP, nilai aksesibilitas

\section{PENDAHULUAN}

Infrastruktur sangat penting bagi perkembangan wilayah dan membantu kegiatan ekonomi dan sosial masyarakat. Daerah yang mempunyai kelengkapan sistem infrastruktur yang lebih baik, mempunyai tingkat laju pertumbuhan ekonomi dan kesejahteraan masyarakat yang lebih baik pula, dibandingkan dengan daerah yang mempunyai kelengkapan infrastruktur yang terbatas. Dengan demikian dapat dikatakan bahwa penyediaan infrastruktur merupakan faktor kunci dalam mendukung setiap kegiatan pembangunan termasuk dalam mendukung pembangunan kawasan perbatasan [1].

Akses pedesaan dapat didefinisikan sebagai kemampuan, tingkat kesulitan penduduk desa untuk menggunakan, mencapai atau mendapatkan barang dan jasa yang diperlukannya [2]. Aksesibilitas mempunyai tiga unsur, yaitu lokasi rumah tangga / pemukiman, lokasi fasilitas/ jasa, serta sistem transportasi yang menghubungkan keduanya [3].

Akses penduduk pedesaan dapat dikelompokkan menjadi tiga kategori umum [2] : (1) Akses yang berhubungan dengan kebutuhan pokok seperti penyediaan air dan sumber energi, (2) Akses yang berhubungan dengan aspek kesejahteraan sosial di pedesaan seperti kesehatan dan pendidikan, (3) Akses yang berhubungan dengan aspek kesejahteraan ekonomi di pedesaan seperti pertanian, perkebunan, peternakan, industri kecil dan lain-lain.

Penyediaan infrastruktur yang memadai merupakan upaya untuk memperbaiki akses penduduk desa. Penyediaan infrastruktur membutuhkan dana yang sangat besar untuk mendanai pembangunan infrastruktur yang menyeluruh dan berkesinambungan. Keterbatasan dana yang ada maka kebutuhan perencanaan infrastruktur harus dilakukan berdasarkan skala prioritas. Oleh karena itu studi ini bertujuan menentukan skala prioritas penanganan aksesibilitas infrastruktur di Desa Kumba Kecamatan Jagoi Babang Kabupaten Bengkayang.

\section{METODOLOGI}

Penelitian ini menggunakan metode IRAP (Integrated Rural Accessibility Planning). Penentuan prioritas penanganan infrastruktur desa dengan metode IRAP ini adalah berdasarkan nilai aksesibilitas tiap infrasrutktur.

\footnotetext{
* Corresponding author. Tel.: +62- 81352597688

E-mail address: ferryjuniardi@gmail.com
} 
Data yang dibutuhkan dalam studi ini terdiri dari data sekunder dan data primer. Data sekunder diperoleh dari instansi terkait seperti Badan Pusat Statistik, kantor kecamatan, dan kantor/sekretariat desa setempat diantaranya data sosial ekonomi dan profil desa. Sementara data primer diperoleh dari observasi lapangan dan survei wawancara. Survei lapangan dilakukan untuk mengamati kondisi dan aksesibilitas infrastruktur yang ada, dan survei wawancara dilaksanakan untuk menjaring persepsi masyarakat mengenai tingkat kesulitan dalam memperoleh kebutuhan sehari-hari terhadap barang dan jasa yang didapa $t$ dari fasilitas sektor-sektor infrastruktur yang ada. Dalam studi ini sektor yang ditinjau antara lain : pendidikan, kesehatan, pertanian, perkebunan, pasar

Tahap pertama dari tahapan analisis ini adalah mempersiapkan/menyusun basis data. Basis data yanag disusun berdasarkan sektor infrastruktur dan kriteria yang dikembangkan terhadap setiap infrastuktur yang mempengaruhi aksesibilitas masyarakat desa.

Tahap kedua adalah penentuan nilai indikator aksesibilitas. Penentuan nilai masing-masing indikator berdasarkan kondisi aksesibilitasnya. Nilai paling rendah menunjukkan indikator tersebut dalam kondisi paling baik, sedangkan nilai paling tinggi berarti kondisi indikator tersebut sangat jelak. Dalam studi ini nilai indikator diurutkan dari 1 sampai 5. Angka 1 berarti kondisi paling baik, sedangkan angka 5 berarti kondisi paling buruk.

Tahap ketiga adalah penentuan bobot indikator. Bobot indikator dalam hal ini merupakan tingkat kepentingan dari masingmasing kriteria yang diberikan 5 pilihan yaitu :

- 5 = indikator sangat penting

- 4 = indikator penting

- 3 = indikator agak penting

- 2 = indikator tidak begitu penting

- 1 = indikator tidak penting

Tahap keempat adalah perhitungan nilai aksesibilitas. Untuk lebih jelas mengenai penentuan nilai aksesibilitas dapat dilihat pada tabel berikut ini :

Tabel 1. Penentuan Nilai Aksesibilitas Total Rata-rata Terhadap Semua Indikator Desa/Sektor yang diteliti

\begin{tabular}{|l|l|l|l|l|l|l|l|l|l|l|l|}
\hline No & Responden & \multicolumn{3}{|c|}{ Nilai Indikator (I) } & \multicolumn{3}{c|}{ Bobot Indikator (B) } & \multirow{2}{*}{ (IixBi) } & Rerata (IixBi) \\
\hline 1. & & $\mathrm{I}_{1}$ & $\mathrm{I} \ldots$ & $\ldots$ & $\mathrm{Ii}$ & $\mathrm{B}_{1}$ & $\mathrm{~B} \ldots$ & $\ldots$ & $\mathrm{Bi}$ & & \\
\hline 2. & & & & & & & & & & & \\
\hline$\ldots$ & & & & & & & & & & & \\
\hline $\mathrm{N}$ & & & & & & & & & & & \\
\hline \\
Total $=$
\end{tabular}

Keterangan :

$$
\begin{aligned}
& \text { Rerata (IixBi) }=\frac{\sum_{i=1}^{i}(\text { IixBi })}{\text { jumlah } \text { indikator }} \\
& \text { Nilai Aksesibilitas }=\frac{\sum_{n=1}^{n} \operatorname{Re} \text { rata }(\text { Iix Bi })}{\text { jumlah responden }}
\end{aligned}
$$

\section{HASIL DAN PEMBAHASAN}

3.1. Gambaran Wilayah Studi

\footnotetext{
* Corresponding author. Tel.: +62- 81352597688

E-mail address: ferryjuniardi@gmail.com
} 
Kalimantan Barat merupakan salah satu provinsi di Indonesia yang berbatasan langsung dengan negara tetangga Malaysia, tepatnya bagian utara dari Provinsi Kalimantan Barat berbatasan dengan negara Serawak, Malaysia. Terdapat 5 (lima) Kabupaten di Kalimantan Barat yang berbatasan dengan negara tetangga Malaysia diantaranya adalah Kabupaten Bengkayang. Ada 2 (dua) kecamatan di Kabupaten Bengkayang yang berbatasan negara tetangga Malaysia tersebut diantaranya adalah Kecamatan Jagoi Babang. Desa kumba merupakan salah satu desa di Kecamatan Bengkayang yang berbatasan dengan negara tetangga Malaysia.

Desa Kumba memiliki batas wilayah yaitu bagian utara berbatasan dengan Malaysia timur, bagain selatan berbatasan dengan Kecamatan Seluas, bagian timur berbatasan dengan Desa Jagoi Sekida, dan bagian barat berbatasan dengan Desa Sinar Baru. Luas Desa Kumbas adalah 65,52 km2 atau 10,00 \% dari luas Kecamatan Jagoi Babang. Jarak Desa Kumba ke ibukota kecamatan adalah $17 \mathrm{~km}$. Desa Kumba terdiri dari 2 (dua) dusun yaitu Dusun Saparan dan Dusun Sindang Kasih, dan terdiri dari 4 Rukun Tetangga. Jumlah penduduk di Desa Kumba pada tahun 2012 sebanyak 2.037 jiwa dengan rata-rata 4 jiwa per keluarga dan memiliki kepadatan penduduk $31 \mathrm{jiwa} / \mathrm{km} 2[4]$.

Sarana pendidikan di Desa Kumba terdiri dari 3 unit SD dan 1 unit SMP. Sarana kesehatan yang ada di Desa Kumba adalah 1 unit puskesmas pembantu dan 1 unit poskesdes. Desa ini sampai saat ini belum dialiri listrik PLN namun pelakai listrik PLN sekitar 220 keluarga [4].

\subsection{Analisis Aksesibilitas Infrastruktur}

\subsubsection{Penentuan Tingkat Aksesibilitas Infrastruktur}

Pada studi ini, infrastruktur yang diamati meliputi : sumber tenaga listrik, sumber air bersih, pendidikan, kesehatan, pasar, perkantoran, komunikasi, industri, pemukiman, pertanian/perkebunan, dan Kamtibmas.

Berdasarkan hasil analisis dengan metode IRAP diperoleh nilai aksesibilitas masing-masing sektor untuk tiap dusun.

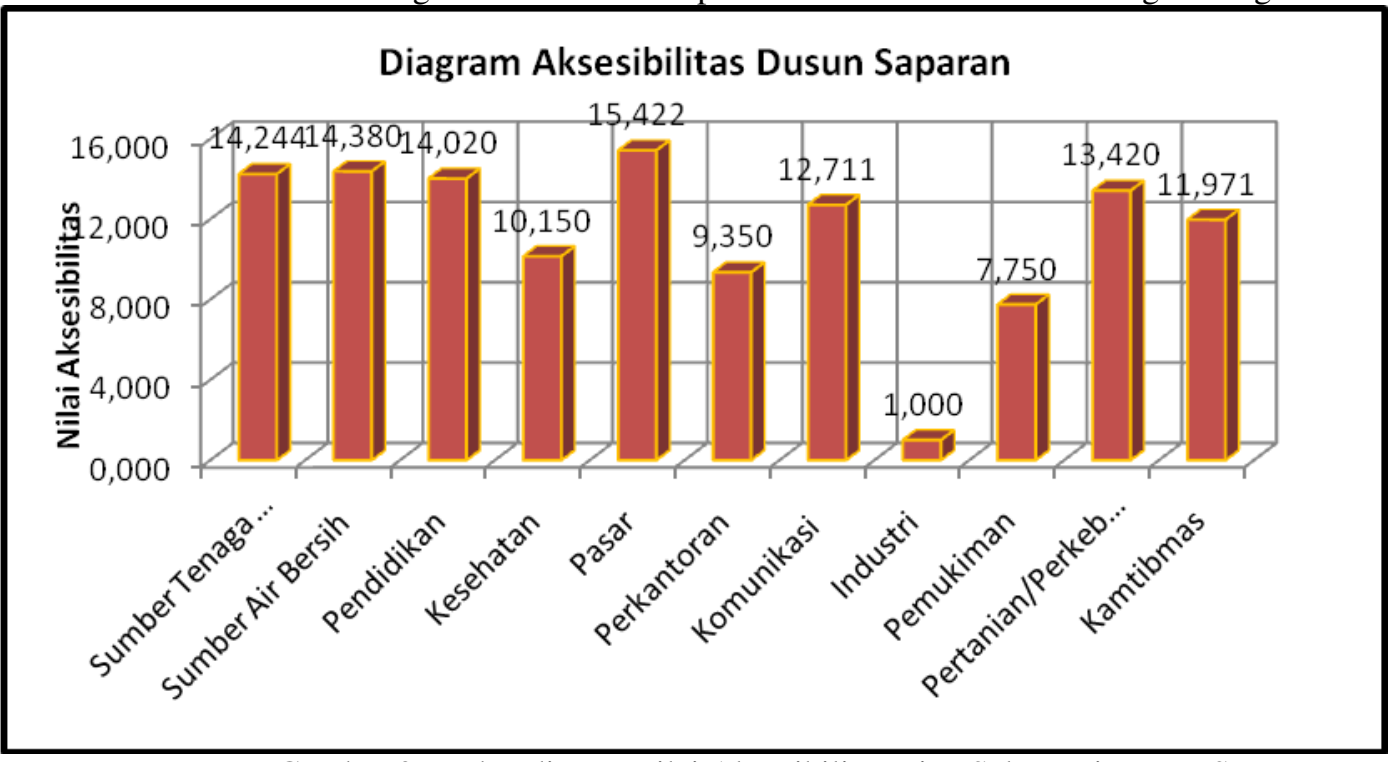

Gambar 2. Perbandingan Nilai Aksesibilitas Tiap Sektor Di Dusun Saparan

Pada perhitungan aksesibilitas di Dusun Saparan Desa Kumba diperoleh nilai aksesibilitas tertinggi pada sektor pasar dengan nilai 15,422, ini berarti adalah tingkat kesulitan terbesar yang dirasakan masyarakat di Dusun Saparan adalah akses terhadap pasar. Sumber air bersih memiliki nilai aksesibilitas urutan kedua terbesar setalah sektor pasar dengan nilai 14,380 yang berarti tingkat kesulitan kedua yang dirasakan masyarakat di Dusun Saparan adalah sektor air bersih. Demikain seterusnya sesuai urutuan nilai aksesibulitas, dan nilai aksesibilitas terendah terdapat pada sektor industri nilai aksesibilitas dianggap 1,000 karena tidak terdapat sektor Industri di Dusun Saparan.

Berdasarkan tingkat aksesbilitas terhadap berbagai infrastruktur di atas, maka berarti bahwa untuk memperbaiki aksesbilitas masyarakat di Dusun Saparan Desa Kumbas adalah di prioritas perbaikan akses terhadap pasar selanjutnya secara berurutan perbaikan akses terhadap air bersih, listrik, pendidikan, pertanian/perkebunanan, komunikasi, kmamtibmas, kesehatan, perkantoran, pemukiman dan prioritas terakhir adalah sektor industri.

\footnotetext{
* Corresponding author. Tel.: +62- 81352597688

E-mail address: ferryjuniardi@gmail.com
} 


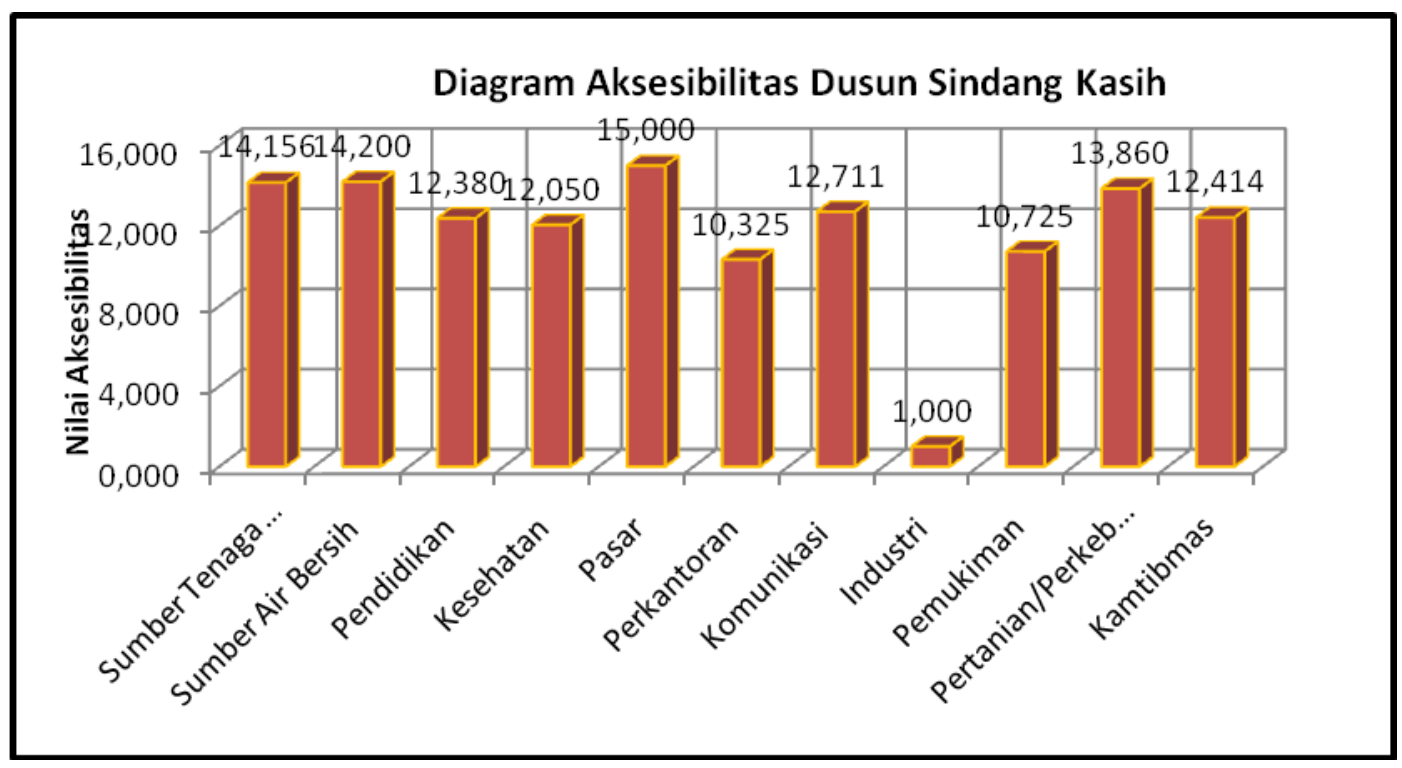

Gambar 3. Perbandingan Nilai Aksesibilitas Tiap Sektor Di Dusun Sindang Kasih

Pada perhitungan aksesibilitas di Dusun Sindang Kasih Desa Kumba diperoleh nilai aksesibilitas tertinggi pada sektor pasar dengan nilai 15,000, ini berarti adalah tingkat kesulitan terbesar yang dirasaakan masyarakat di Dusun Sindang Kasih adalah akses terhadap pasar. Sumber air bersih memiliki nilai aksesibilitas urutan kedua terbesar setalah sektor pasar dengan nilai 14,200 yang berarti tingkat kesulitan kedua yang dirasakan masyarakat di Dusun Sindang Kasih adalah sektor air bersih. Demikain seterusnya sesuai urutuan nilai aksesibulitas, dan nilai aksesibilitas terendah terdapat pada sektor industri nilai aksesibilitas 1,000.

Berdasarkan tingkat aksesbilitas terhadap berbagai infrastruktur di atas, maka berarti bahwa untuk memperbaiki aksesbilitas masyarakat di Dusun Sindang Kasih Desa Kumbas adalah di prioritas perbaikan akses terhadap pasar selanjutnya secara berurutan perbaikan akses terhadap air bersih, listrik, pertanian/perkebunanan, pendidikan, komunikasi, kamtibmas, kesehatan, pemukiman, perkantoran, dan prioritas terakhir adalah sektor industri.

Jika dibandingkan nlai aksesibilitas antar dusun. Dusun Saparan mendapat prioritas pada sektor tenaga listrik, air bersih, pendidikan, dan pasar, sedangkan Dusun Sindang Kasih mendapatkan prioritas pada sektor kesehatan, perkantoran, pemukiman, pertanian/perkebunan, dan kamtibmas. Prioritas yang seimbang diantara dua dusun tersebut adalah sektor komunikasi dan industri.

\subsubsection{Penentuan Strategi Penanganan Aksesibilitas Infrastruktur}

Sesuai dengan metode yang digunakan yaitu IRAP maka intervensi penangan aksesibilitas infrastruktur terdiri intervensi non-transportasi dan intervensi transport. Dalam studi ini intervensi non-transport berupa pebaikan atau peningkatan fasilitas sarana infrastruktur dan intervensi transport berupa perbaikan sarana dan prasarana transportasi.

Untuk melihat prioritas intervensi yang akan dilakukan adalah dengan melihat perbandingan nilai aksesibilitas dari fasilitas, sarana dan prasarana transportasi. Rekapitulasi perbandingan nilai dari fasilitas, sarana dan prasarana transportasi sebagai berikut ::

Tabel 1. Perbandingan Nilai Aksesibilitas Indikator Fasilitas, Prasarana dan Sarana Transportasi di Dusun Saparan

\begin{tabular}{|c|l|c|c|c|}
\hline \multirow{2}{*}{ No } & \multirow{2}{*}{ Sektor } & \multicolumn{3}{|c|}{ Nilai Aksesibilitas } \\
\cline { 3 - 5 } & & Fasilitas & Sarana & Prasarana \\
\hline 1 & Tenaga Listrik & 5,00 & 7,20 & 12,00 \\
\hline 2 & Air Bersih & 15,00 & 17,00 & 13,60 \\
\hline 3 & Pendidikan & 15,00 & 18,00 & 12,00 \\
\hline 4 & Kesehatan & 8,00 & 15,00 & 9,00 \\
\hline 5 & Pasar & 20,00 & 8,40 & 15,20 \\
\hline
\end{tabular}

\footnotetext{
* Corresponding author. Tel.: +62- 81352597688
}

E-mail address: ferryjuniardi@gmail.com 


\begin{tabular}{|c|l|r|c|c|}
\hline \multirow{2}{*}{ No } & \multirow{2}{*}{ Sektor } & \multicolumn{3}{|c|}{ Nilai Aksesibilitas } \\
\cline { 3 - 5 } & & Fasilitas & Sarana & Prasarana \\
\hline 6 & Kantor & 16,00 & 9,00 & 9,00 \\
\hline 7 & Komunikasi & 13,80 & 9,00 & 10,80 \\
\hline 8 & Industri & 1,00 & 1,00 & 1,00 \\
\hline 9 & Pemukiman & 1,00 & 13,00 & 9,00 \\
\hline 10 & Pertanian/Perkebunan & 18,00 & 8,00 & 12,00 \\
\hline 11 & Kamtibmas & 22,00 & 6,00 & 9,00 \\
\hline
\end{tabular}

Berdasarkan tabel di atas diketahui bahwa Dusun Saparan memiliki prioritas utama yaitu pada Sektor Pasar, Sektor Pertanian/Perkebunan dan Kamtibmas dengan nilai aksesibilitas fasilitas masing-masing sebesar 20,000 , 18,000 dan 22,000. Peningkatan aksesibilitas ini akan dilakukan dengan pendekatan intervensi, yaitu pada Sektor Pasar dengan membangun pasar yang dapat dengan mudah diakses warga. Sedangkan Sektor Pertanian/Perkebunan adalah dengan membuat tempat penampungan dan penjualan hasil pertanian/perkebunan serta menyediakan bahan - bahan keperluan pertanian di dekat dusun tersebut. Sedangkan Sektor Kamtibmas adalah dengan membuat pos keamanan di dekat dusun tersebut.

Pada nilai aksesibilitas sarana transportasi yang mendapat prioritas utama yaitu pada Sektor Sumber Air Bersih, Pendidikan dan Kesehatan dengan nilai aksesibilitas sarana masing-masing sebesar 17,000 , 18,000 dan 15,000. Peningkatan aksesibilitas prasarana transportasi dilakukan dengan pendekatan intervensi. Pendekatan intervensi nya adalah dengan membuat jaringan pipa untuk mengalirkan air dari danau serta mengadakan angkutan umum untuk transportasi ke tempat fasilitas kesehatan dan angkutan sekolah.

Pada indikator aksesibilitas prasarana transportasi yang mendapatkan prioritas utama yaitu pada Sektor Sumber Air Bersih dan Pasar dengan nilai sebesar 13,600 dan 15,200. Peningkatan aksesibilitas prasarana transportasi adalah dengan memperbaiki kualitas jalan dari jalan batu menjadi jalan aspal untuk mempermudah akses transportasi.

Tabel 2. Perbandingan Nilai Aksesibilitas Indikator Fasilitas, Prasarana dan Sarana Transportasi di Dusun Sindang Kasih

\begin{tabular}{|c|l|c|c|c|}
\hline \multirow{2}{*}{ No } & \multicolumn{1}{|c|}{ Sektor } & \multicolumn{3}{|c|}{ Nilai Aksesibilitas } \\
\cline { 3 - 5 } & & Fasilitas & Sarana & Prasarana \\
\hline 1 & Tenaga Listrik & 5,00 & 6,80 & 12,00 \\
\hline 2 & Air Bersih & 23,00 & 15,00 & 12,00 \\
\hline 3 & Pendidikan & 11,00 & 14,40 & 12,00 \\
\hline 4 & Kesehatan & 21,60 & 11,40 & 9,00 \\
\hline 5 & Pasar & 20,00 & 6,80 & 12,00 \\
\hline 6 & Kantor & 16,00 & 6,60 & 6,60 \\
\hline 7 & Komunikasi & 13,80 & 9,00 & 9,60 \\
\hline 8 & Industri & 1,00 & 1,00 & 1,00 \\
\hline 9 & Pemukiman & 1,00 & 8,00 & 10,20 \\
\hline 10 & Pertanian/Perkebunan & 18,00 & 8,00 & 12,00 \\
\hline 11 & Kamtibmas & 22,00 & 6,00 & 9,00 \\
\hline
\end{tabular}

Berdasarkan tabel diatas diketahui bahwa pada Dusun Sindang Kasih memiliki prioritas utama yaitu pada Sektor Sumber Air Bersih, Sektor Kesehatan Dan Kamtibmas dengan nilai aksesibilitas fasilitas masing-masing sebesar 23,000 , 21,600 dan 22,000. Peningkatan aksesibilitas ini akan dilakukan dengan pendekatan intervensi, yaitu pada sektor sumber air bersih dengan menyediakan PAH untuk warga dusun. Sedangkan Sektor Kesehatan adalah dengan menambah perlengkapan medis dan petugas di posyandu dusun tersebut. Sementara Sektor Kamtibmas adalah dengan membuat pos keamanan di dekat dusun tersebut.

\footnotetext{
* Corresponding author. Tel.: +62- 81352597688

E-mail address: ferryjuniardi@gmail.com
} 
Pada nilai aksesibilitas sarana transportasi yang mendapat prioritas utama yaitu pada Sektor Sumber Air Bersih, Pendidikan dan Kesehatan dengan nilai aksesibilitas sarana masing-masing sebesar 15,000 , 14,400 dan 11,400. Peningkatan aksesibilitas prasarana transportasi dilakukan dengan pendekatan intervensi. Pendekatan intervensi nya adalah dengan membuat jaringan pipa untuk mengalirkan air dari danau serta mengadakan angkutan umum untuk transportasi ke tempat fasilitas kesehatan dan angkutan sekolah.

Pada indikator aksesibilitas prasarana transportasi yang mendapatkan prioritas utama yaitu pada Sektor Sumber Air Bersih, Sumber Tenaga Listrik, Pendidikan, Kamtibmas dan Pasar dengan nilai yang sama sebesar 12,000. Peningkatan aksesibilitas prasarana transportasi adalah dengan memperbaiki kualitas jalan dari jalan batu menjadi jalan aspal untuk mempermudah akses transportasi.

\section{KESIMPULAN}

1. Tingkat kesulitan terbesar yang dirasakan masyarakat di Dusun Saparan dan Dusun Sidang Kasih adalah akses terhadap pasar dengan nilai aksesibilitas masing-masing sebesar 15,422 dan 15,000, dengan demikian prioriritas utama penangan aksesibilitas di kedua dusun tersebut adalah sektor pasar.

2. Intervensi perbaikan aksesibilitas infrastruktur pada Dusun Saparan dari sisi perbaikan/pembangunan fasilitas infrastruktur adalah pasar, perkantoran, komunikasi, pertanian/perkebunan dan kamtibmas, intervensi dari sisi sarana transportasi berupa penyediaan angkutan umum yaitu sektor air bersih, pendidikan, kesehatan, dan pemukiman, dan intervensi dari sisi prasarana transportasi berupa perbaikan jalan adalah sektor tenaga listrik.

3. Intervensi perbaikan aksesibilitas infrastruktur pada Dusun Sindang Kasih dari sisi perbaikan/pembangunan fasilitas infrastruktur adalah air bersih, kesehatan, pasar, perkantoran, komunikasi, pertanian/perkebunan dan kamtibmas, intervensi dari sisi sarana transportasi berupa penyediaan angkutan umum yaitu sektor pendidikan, dan intervensi dari sisi prasarana transportasi berupa perbaikan jalan adalah sektor tenaga listrik dan pemukiman.

\section{UCAPAN TERIMA KASIH}

Penulis mengucapkan terima kasih yang sebesar-besarnya kepada pihak-pihak yang telah membantu dalam setiap atau sebagian tahapan dari studi ini baik langsung maupun tidak langsung

\section{DAFTAR PUSTAKA}

[1] H. Azwansyah and F. Januardi, Studi Pengelolaan Infrastruktur Dasar Kecamatan Telok Batang Kabupaten Kayong Utara Studi Kasus Desa Sungai Paduan dan Desa Mas Bangun, Jurnal Langkau Betang. Prodi Arsitektur Fakultas Teknik Sipil Untan, 2014.

[2] C. Donnges, Rural Access and Employment, The Laos Experience. Development Policies Departement. Geneva: ILO office Geneva, 1999.

[3] R. Dennis, Rural Transport and Accessibility. Development Policies Departement. Geneva: ILO office Geneva, 1998.

[4] BPS Kab. Bengkayang, "Kecamatan Jagoi Babang Dalam Angka," 2013.

\footnotetext{
* Corresponding author. Tel.: +62- 81352597688

E-mail address: ferryjuniardi@gmail.com
} 